\title{
THE ACCESS OF SMALL AND MEDIUM SIZE ENTERPRISES TO BANKING FINANCING AND CURRENT CHALLANGES: THE CASE OF EU COUNTRIES
}

\author{
Angela Roman ${ }^{l}$ \\ Valentina Diana Rusu ${ }^{2}$
}

\begin{abstract}
Bank loans are a vital resource for SMEs financing because of the reduced possibilities of these firms to find alternative sources of financing. In the context of the current crisis, the access to loans for SMEs has deteriorated significantly due to lower availability of bank loans, that can hamper the exit from the crisis of these firms and the relaunch of the national economies. Moreover, the adoption of the new banking regulations by Basel III Accord raises concerns about their possible negative impact on bank financing of SMEs. In this context, our paper aims to highlight a few features of bank financing of SMEs in EU member states and to bring into question the impact of new banking regulations on loans flow to SMEs.
\end{abstract}

Keywords: Small and medium sized enterprises, EU, access to finance, bank loans, Basel III

JEL Codes: G21, G32, O16

\section{Introduction}

Small and medium sized enterprises have a vital importance for the economies of the European Union member states by contributing significantly to the economic growth and to job creation. Thus, the small and medium size enterprises represent $99,8 \%$ from the total of the European firms, providing two thirds from the total jobs and 58\% from the added value of the European economy. However, the survival and enhancement of these firms is conditioned by providing easy access to finance, especially on bank loans which are the most important resource for external financing of these companies. Unlike the large enterprises, the medium and small size enterprises have fewer financing alternatives, which lead to their overwhelming dependence on banks.

In the context of the recent financial crisis the drastic drop of the credit flows toward the real economy as a result of the significant diminishing of both the supply and demand of loans, that has major negative implications on the survival and the relaunch of the small and medium size enterprises sector. The access to banks loans of the small and medium size enterprises sector has deteriorated significantly due to lower availability of bank loans. Moreover, the adoption of the new banking regulations, at international and European level, caused anxieties regarding their potential negative impact on credit flows to SMEs.

In this context, our paper aims to highlight some key features of access to bank financing of SMEs in EU27 and discuss the potential negative impact of the current challenges represented especially by Basel III Accord on bank lending capacity to the real economy, especially to SMEs, which could lead to a delayed recovery of European economies.

The analysis conducted in this paper is based mainly on data and statistics of European Central Bank, the European Commission, the World Bank and other different reports and research papers.

\footnotetext{
${ }^{1}$ „Alexandru Ioan Cuza” University of Iasi, Romania, e-mail: aboariu@uaic.ro

„Alexandru Ioan Cuza” University of Iasi, Romania, e-mail: valentinadiana.ig@ gmail.com
} 
Our paper focuses on three main areas. The first part of the study is dedicated to a brief literature review with the purpose to highlight the place of our research. The second part highlights recent trends in SMEs financing in the European Union countries, while the last part of the paper brings into question the current challenges faced by SMEs in procuring financial resources and here we analyze the Basel III Accord. The study ends with conclusions.

\section{Literature review}

The SMEs tend to be more financially constrained than large firms and the lack of access to finance is an important obstacle to their growth (De la Torre, Martinez Peria and Schmukler, 2008; Beck, Demirgüç-Kunt and Martínez Pería, 2009; Beck, Demirgüç-Kunt and Martínez Pería, 2011). Most of the times, SMEs face significant constraints when seeking the financing resources they need for their activities, constraints which are more important than those faced by larger firms (ECB, 2011; Barth, 2011). The research undertaken by Schiffer and Weder (2001) underlines that the small size firms are facing major obstacle in their development compared with the medium and large size firms.

Beck, Demirguc-Kunt, Laeven \& Maksimovic (2006) using a sample composed from over 10.000 firms from 80 countries analyse the relationship between the characteristics of the firms and the difficulties that they face in the financing process. The authors demonstrate that the financing difficulties significantly depend on their age, size and ownership structure. Thus, the young firms, small size and nationally owned are facing the most important difficulties in the procurement of financing resources. The study underlines that the difficulties in the financing of the firms significantly depend on the development level of the financial intermediation process, of the stock markets, on the efficiency of the juridical system and the GDP per capita. Concluding, the authors underline the fact that the financing of the firms are different from one country to another, especially as a result of the different level of institutional development.

De la Torre, Martinez Peria and Schmukler (2008) and Hernandez-Canovas and MartinezSolano (2010) showed that despite the differences in the economic environment of countries in terms of rules, regulations, and ease of doing business, the small and medium size enterprise sector has become a very attractive market segment for most banks in the European Union. Because of this, banks have begun to target SMEs due to significant competition both in the corporate and the retail sectors. Currently, banks have started to perceive the SME market as being a large, highly profitable market and with very good prospects.

The relationships between banks and SMEs represent a subject for many studies in the academic literature, underlining especially the main barriers which appear in the development of these firms. For example, the study of Mercieca, Schaeck and Wolfe (2009) is focused on the analysis of the way in which competition from the banking sector impacts the number of bank lending relationships that SMEs has. The results of the study suggests that while the level of banking competition has a significant and important impact on the number of banking lending relationships, the concentration level of the banking sector has a strong negative impact. Through the removal of the barriers and the obstacles that prevent the development and the multiplication of the relationships between the banks and SMEs can insure the development of these firms and also an easy access to more and more sophisticated financial services, thus insuring implicitly the promoting of economic growth. The study of Ardic, Mylenko and Saltane (2011) analyse the main macroeconomic and institutional factors that have an impact on the loans granting process to the SMEs. Thus the authors conclude based on the undertaken analysis that the income per capita, the ratio of private credit to GDP, the juridical and business environment and the efficiency of the banking sector represent the most important factors that influence the loans granting process to SMEs.

SMEs are restricted when trying to choose the form of financing which they will use. Traditionally, bank loans are the main instrument for SMEs financing: about $80 \%$ of the financing 
volume is covered this way. The financing instruments related to capital market are not available for the most SMEs because of the necessary volumes and documentation requirements. This dependence on bank loans leads to problems when there are significant changes in the bank lending due to legislative changes (Angelkort and Stuwe, 2011).

Currently, the Basel III Accord proposes a series of reforms for the enhancement of the resistance and the stability of the financial system, such as the contagion risk from the financial sector to the real economy is reduced (Bank for International Settlements, 2010). We can acknowledge through the impact of Basel III on the economy that a large part of the studies undertaken so far have been focused on the evaluation of the impact that the new regulations had at the macroeconomic level, on the GDP respectively, and to a lesser extent on the evaluation of the potential impact at the macroeconomic level, on the financing through banking loans of the firms, especially of the small and medium size enterprises.

Some authors (Angelkort and Stuwe, 2011) consider that under the impact of Basel III is likely to be registered an increase in the cost of borrowed capital or the access to borrowed capital will become more difficult as a result of higher demands on the quality of loans.

Altman and Sabato (2005) have shown that under these conditions of continuous banking reforms, banks should develop and implement some scoring systems and procedures specific for SMEs in order to effectively manage and improve the profitability of the SME segment. Banks should not only apply different procedures to manage SME customers compared to large corporate companies, but they should also use specific tools (such as scoring and rating systems), targeted in particular to SMEs portfolio.

Furthermore Angelkort and Stuwe (2011) believe that there must be found a new „compromise for SMEs” for Basel III, similar to the one which has been established for Basel II, so that the capital requirements for loans to SMEs not to be raised allowing these firms to continue to access financial resources from banks.

\section{Particularities of SMEs bank financing in the EU27}

Easy access to finance for SMEs is very important both for their current activity and also for the investment activity and achieving their growth objective. On the other hand, the access to financing represents one of the most important challenges for the SMEs, both in normal conditions that lack turbulences, but especially in crisis conditions.

In the case of the European countries, the survey on the access to finance of SMEs in the European Union, undertaken by the European Commission and the ECB during the period AugustOctober 2011, shows that the access to finance for SMEs continue to be, as in 2009, the second most pressing problem for these firms, and the most pressing problem remains finding customers (see fig. no. 1). 


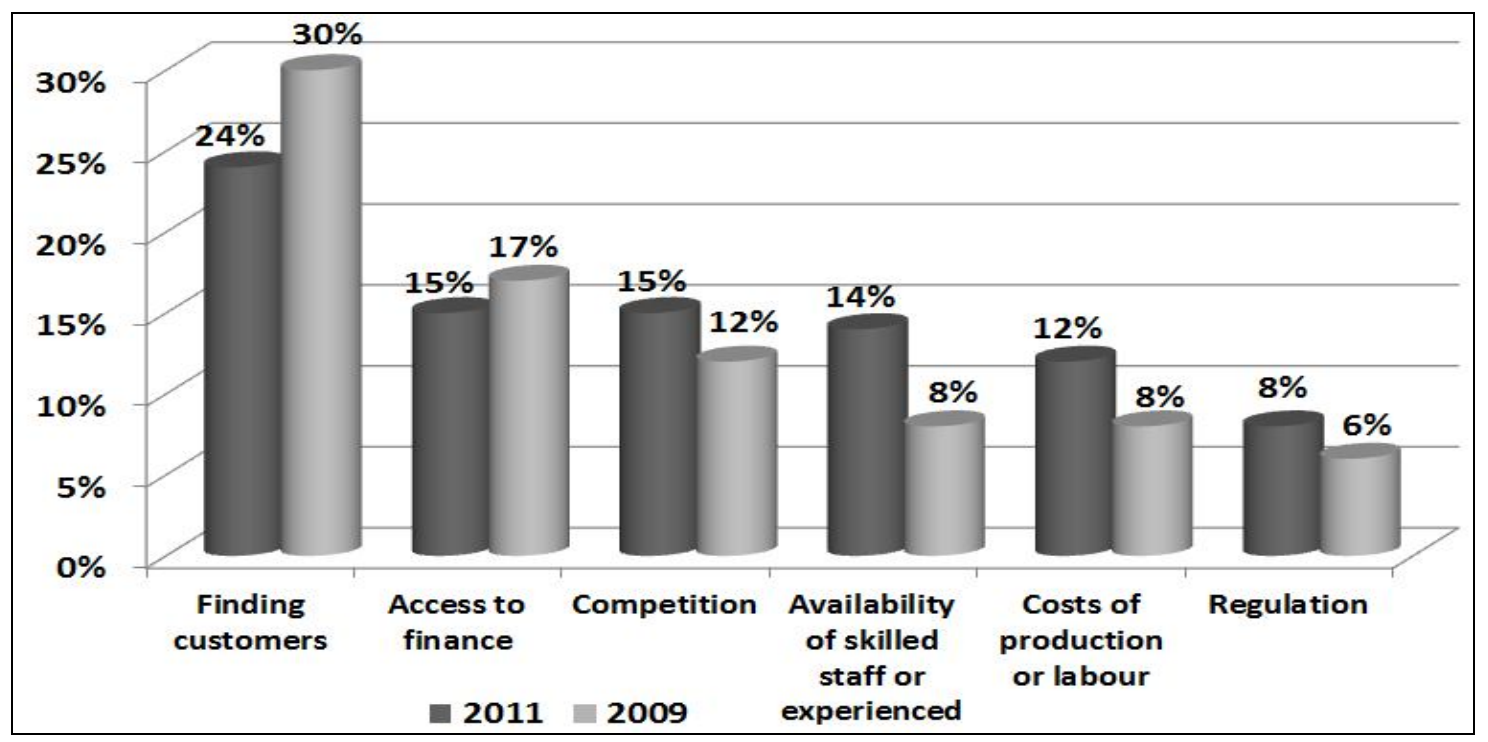

Fig. no. 1 - The most pressing problems of the EU SMEs

Source: (European Commission, 2011a)

According to the mentioned survey, there was a slight decrease in 2011 compared to 2009 in the percentage of SMEs that reported finding customers and the access to finance as the most pressing problems.

Regarding the financing resources of the SMEs activity we observe that in 2009 the internal funds were the main source of financing for the SMEs in the European Union, $49 \%$ of them turning to this source of financing, in 2011 the situation changed, the use of internal funds for financing SMEs in the European Union has decreased, (only $24 \%$ of SMEs used internal funds as a source of financing) instead has increased the use of other financing sources. Thus, in 2011, the main source of financing used by the European SMEs was bank overdrafts (40\%), followed by leasing / hire purchase / factoring (36\%), trade credit (32\%) and bank loans (30\%). It is worth noting that in the last two years there have been registered a significant increase in the use of leasing (28\% in 2009 to $36 \%$ in 2011) and trade credit (from 17\% in 2009 to $32 \%$ in 2011). One reason could be the fact that SMEs have meet difficulties in procuring traditional sources of financing (resources from banks) and, because of that, they try to use a series of alternative resources in order to satisfy their financing needs.

Analyzing fig. no. 2 we observe that $13 \%$ of the SMEs have used other loans, and also $13 \%$ have used grants or subsidized bank loans. In the same time, only $7 \%$ of the analyzed SMEs used equity and only a few used subordinated loans $(2 \%)$ and debt securities issued (2\%) to finance their activity. 


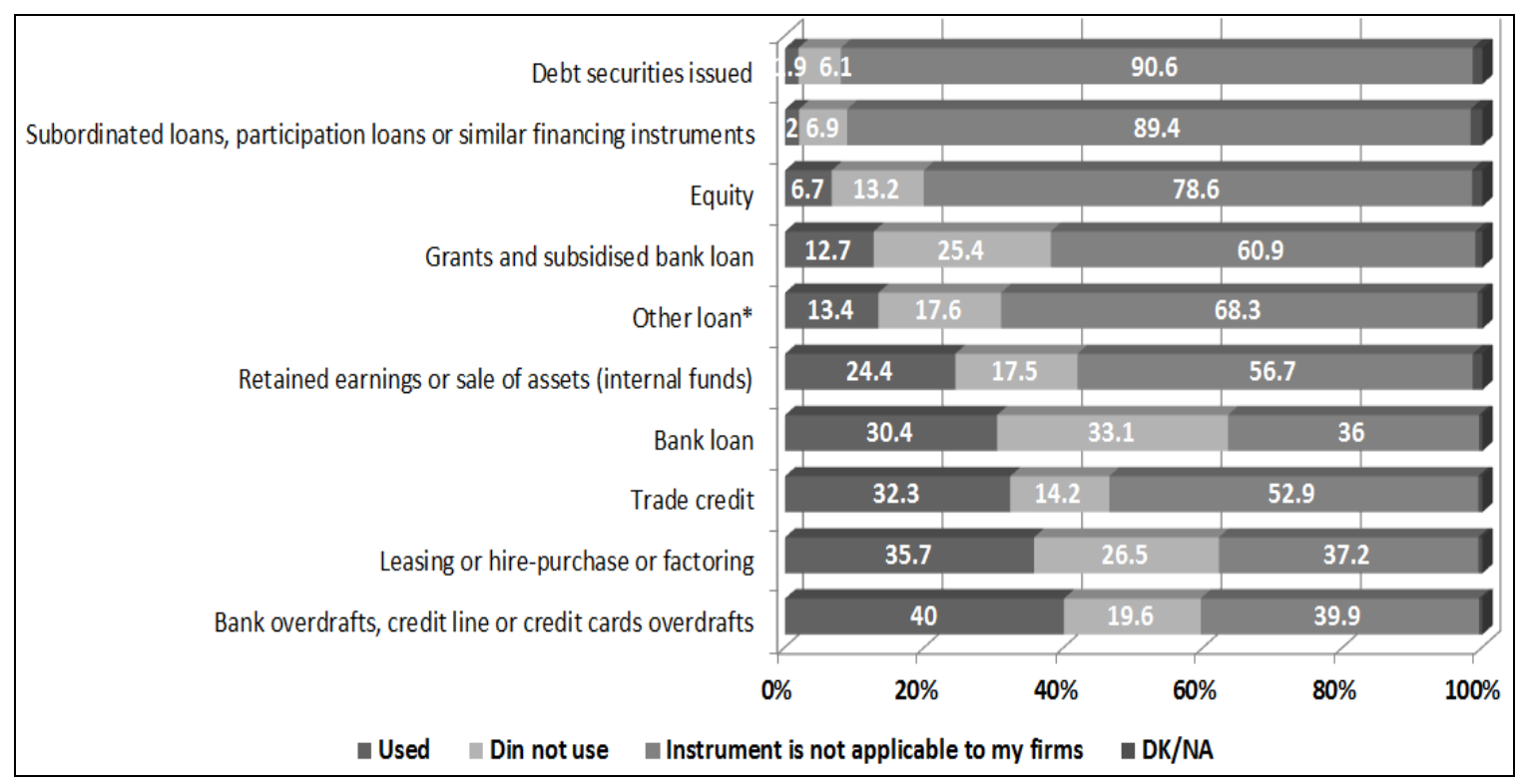

Fig. no. 2. - The SMEs use of internal and external financing in 2011

Source: (European Commission, 2011a:18)

The recent global financial crisis had major negative effects on the SMEs financing from the EU countries. Thus, the survey undertaken in the fourth quarter of the 2010 by the EIM Business \& Policy Research in collaboration with the European Commission (De Kok et al., 2011) underlines as major negative effects the shortage of working capital by $31 \%$ of the micro-enterprises and $19 \%$ of the small and medium size enterprises, shortage of long term finance reported by $28 \%$ by microenterprises and by $21 \%$ between small and medium size enterprises, while also the growth of the interest rates that has been signalled by the $30 \%$ micro-enterprises and $25 \%$ of the SMEs respectively (Roman A., 2012) (see figure 3). As a result, we can remark the major difficulties that are faced by the micro-enterprises and SMEs in their efforts to obtain financial resources.

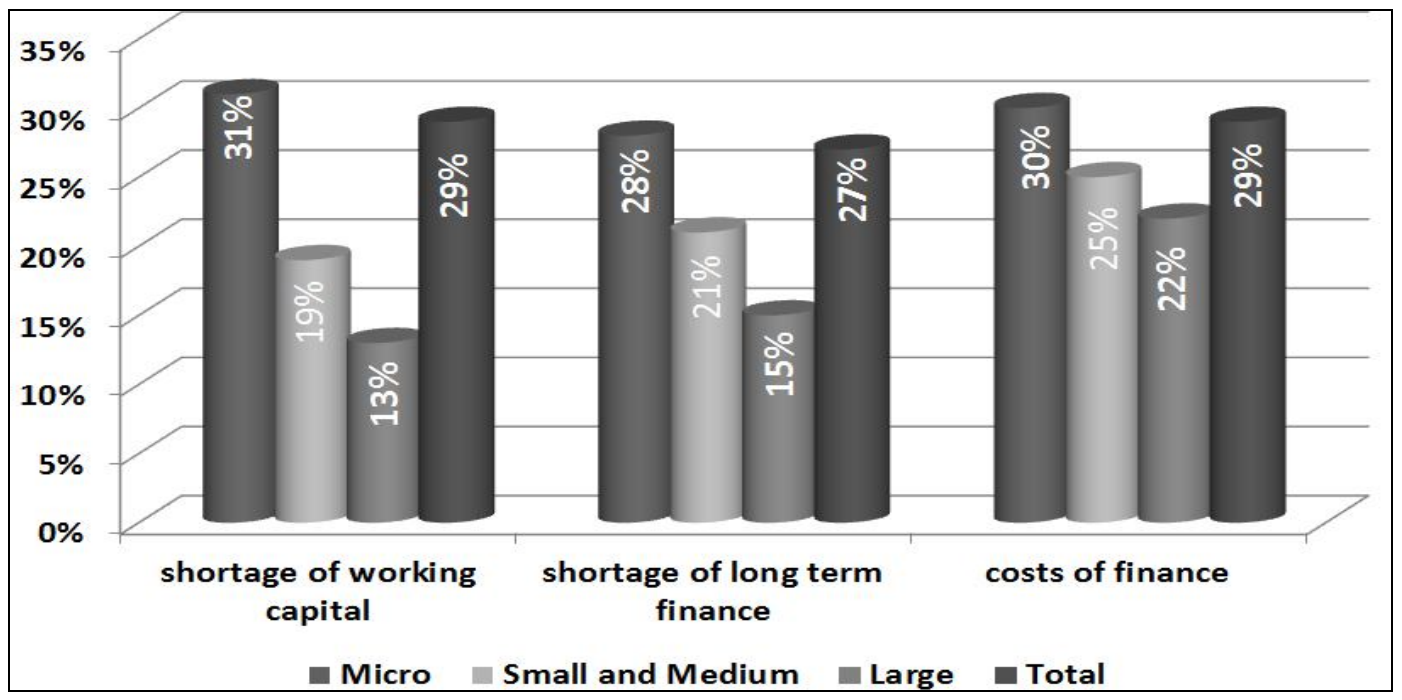

Fig. no. 3. - The main negative effects of the current financial crisis on firms financing, from EU27, in the period 2008 Q4- 2010 Q4

Source: processing based on De Kok et al., 2011:163

Easy access to financing of the SMEs has a crucial importance for their survival and development, this determining the European Commission to construct an index to measure the access to finance of the SMEs sector (SMAF) which allows monitoring the developments registered 
in the EU Member States regarding the access to finance of these types of firms, but also the differences between countries. This index was constructed because of the vital role of easy access to finance for growth and development of European SMEs. SMAF is built from two sub-indexes, because of the reduced availability of statistical data. These sub-indexes are: the access to credit and the access to venture capital. So, the SMEF index is a weighted geometric mean of the two subindexes mentioned, with the weights assigned ( $90 \%$ for debt finance and $10 \%$ for equity finance), which shows the share of each of the two financing methods in the overall external financing of SMEs.

In fig. no. 4 we observe the evolution of the SMAF index in the European Union member countries. Thus, we see that Luxembourg is the only country where the value of the index was at least 120 in each year.

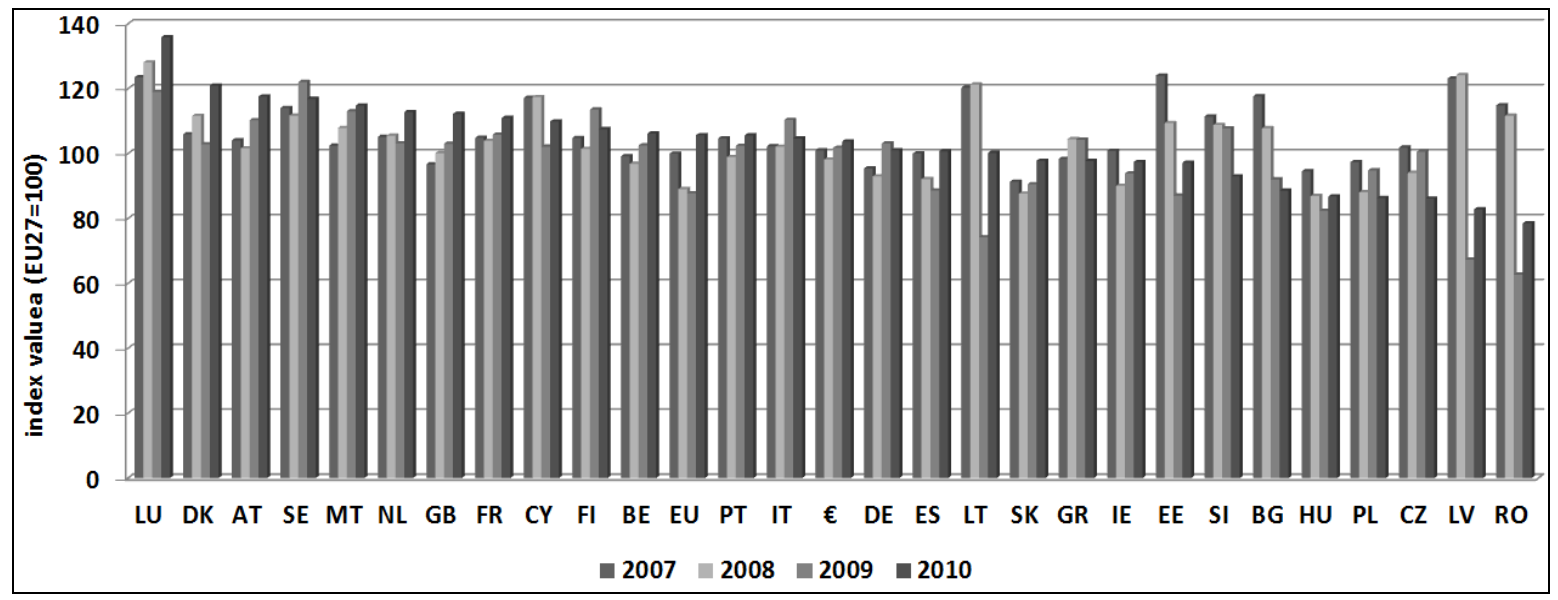

Fig. no. 4. - The evolution of SMAF index in the EU member states, in the period 2007-2010

Source: http://ec.europa.eu/enterprise/policies/finance/data/enterprise-finance-index/sme-access-to-financeindex/index_en.htm

In the context of the current global financial and economic crisis we observe that in most EU states the value of the index decreased, the most dramatic reductions were registered in Latvia, Romania, Lithuania, Estonia and Bulgaria (see fig. no.4), reflecting the serious deterioration in the availability of financing for the SME sector. In 2010, we observe the distribution of the EU Member States between two extremities (see fig. no. 4), as follows: at the upper extremity we find the countries with the value of the index well above the EU average, such as: Luxembourg, Denmark, Austria, Sweden, Malta, Netherlands and the United Kingdom, in the same time the states appear at lower extremity have the lowest value of the index, well below the EU average: Romania and Latvia.

The access to bank loans can be highlighted by a sub-index, which, as we mentioned before, is a component of the SMAF index. The sub-index "access to bank loans" is calculated based on loans volumes and on interest rates and provides information regarding the availability of bank financing for SMEs. Based on data from fig. no. 5 we observe that Luxembourg recorded the highest value of this sub-index (141.48), while Romania has registered the lowest value, respectively 78.97. It is also noteworthy that in ten of the EU member states (mostly non-euro area countries) there have been scored values lower than the reference point of the index, which reflects the reduced availability of bank loans to SMEs in those countries. 


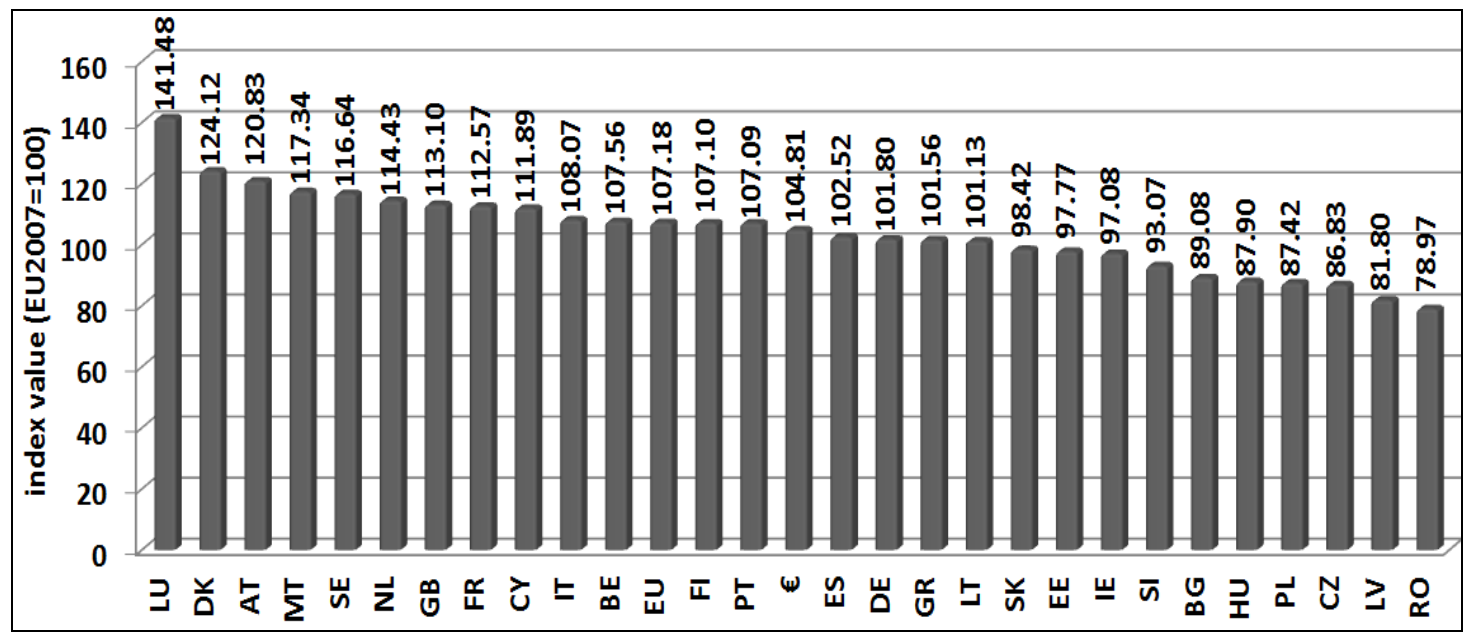

Fig. no. 5. - The value of the sub-index ,access to bank loans” in the EU member states, in 2010

Source: http://ec.europa.eu/enterprise/policies/finance/data/enterprise-finance-index/sme-access-to-financeindex/index_en.htm

Closely related to access to bank loans, it is of interest knowing the ranking of countries according to the ease of getting credit, which is based on two elements: the depth of credit information index and the strength of legal rights index (World Bank, 2011: 48). According to the Doing Business Report (2012), published by the World Bank and International Finance Corporation, the results for "getting credit" for EU countries (except Malta) covered by the report indicates that the best performing economies in the EU in "getting credit" were the UK (ranked first among the 183 countries surveyed), followed by Latvia, Bulgaria, Ireland, Poland and Romania (see fig. no. 6).

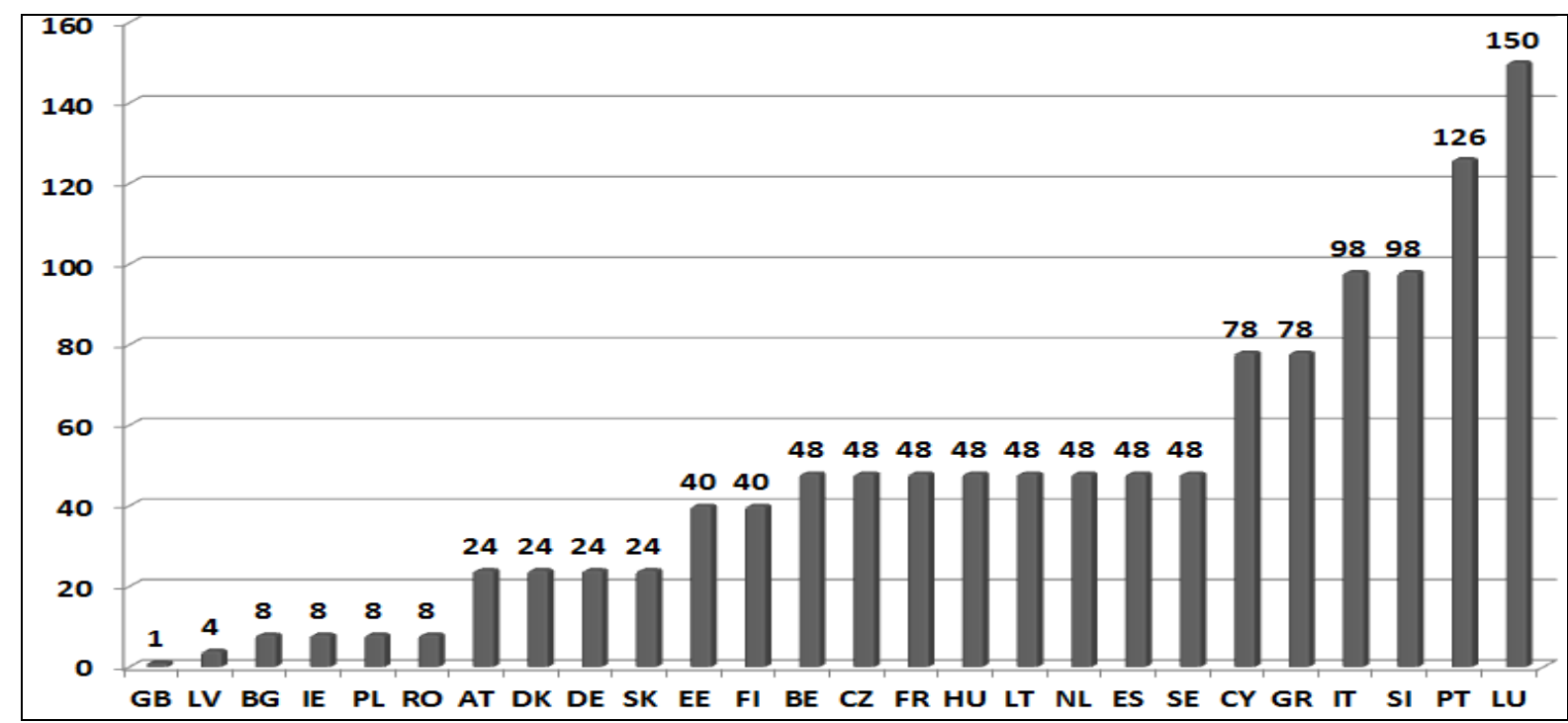

Fig. no. 6. - The ranking of countries according to the value of "getting credit" indicator, June 2011

Sursa: processing based on World Bank, 2011

In the EU member countries, bank loans are a vital resource of SMEs financing because this firms do not have direct access to financial markets, and the venture capital markets are underdeveloped. Thus, according to SAFE (2011) banks were the most popular providers of loans to SMEs, $87 \%$ obtained the loan from a bank, while only $4 \%$ obtained their loans from individuals 
such as family or friends and 9\% got their loan from other sources such as microfinance institutions or government-related sources (see fig. no. 7). These proportions were similar to the ones registered in 2009.

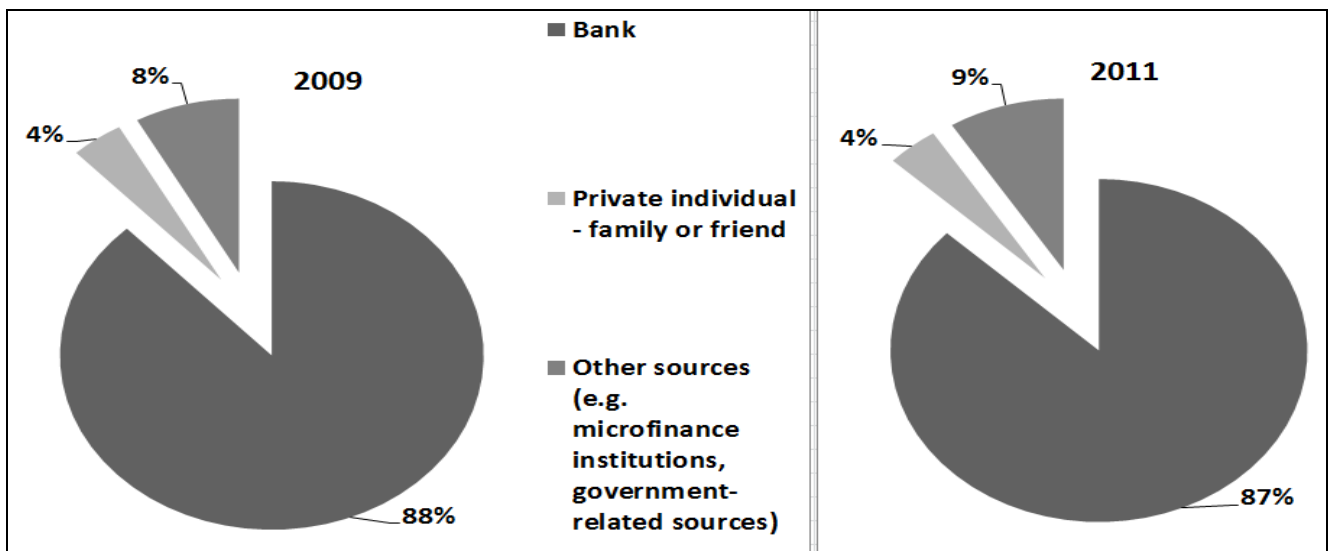

Fig. no. 7. - Provider of the most recent loan for the SMEs from EU27 in 2011 compared to 2009

Source: (European Commission, 2011a: 35)

Although bank financing is the most important source of financing used by the European SMEs we observe the fact that the access to bank loans has deteriorated for SMEs in the EU in the last years, because of the current financial crisis, fact that is confirmed also by the results of the SAFE survey (2011), which shows that about two-thirds (63\%) of SMEs in the EU27 who have applied for a bank loan during April-September 2011 have fully received the required amount, 11\% of the applications were rejected, $17 \%$ received less than requested, and $4 \%$ declined the offer of the banks due to unacceptable conditions (see fig. no. 8).

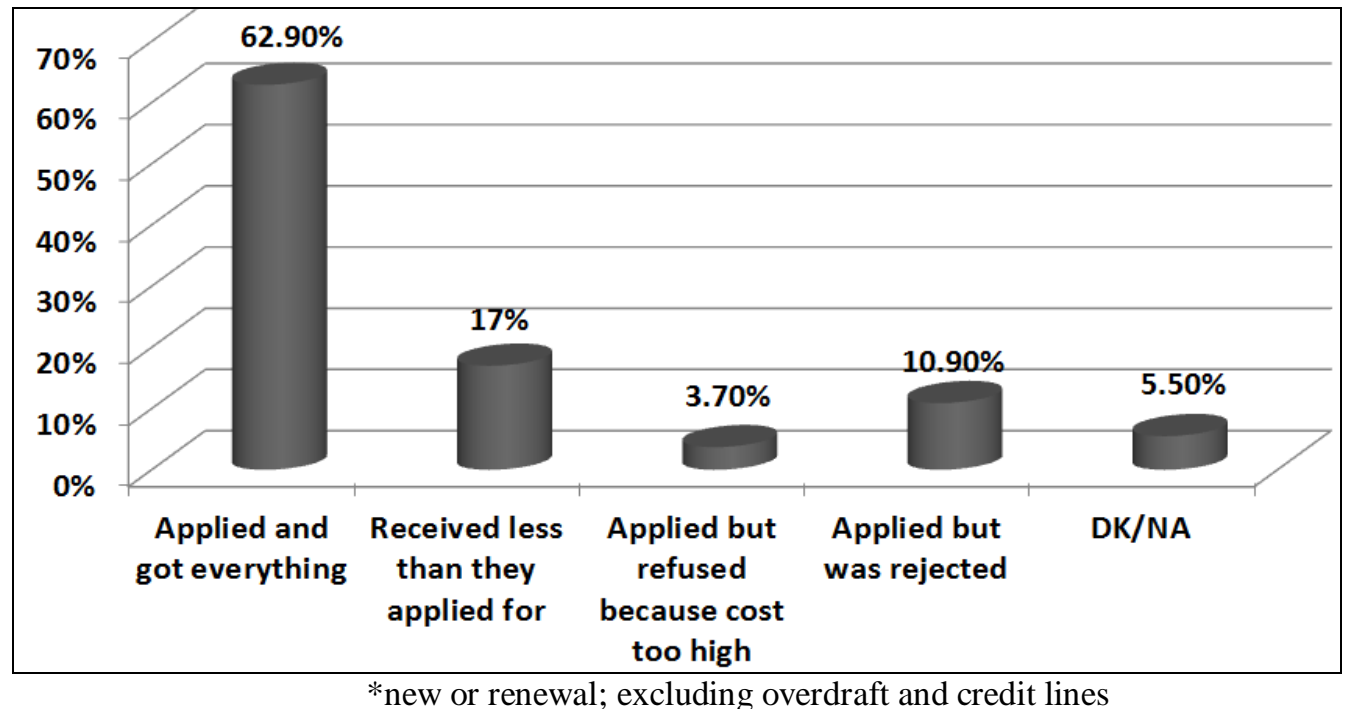

Fig. no. 8. - The results of bank loans applications * of the SMEs from EU27

Source: (European Commission, 2011a)

To analyze the changes that have occurred in the last years regarding the access to bank loans of SMEs we will examine the changes in the terms and conditions of bank lending to SMEs in the European Union. In fig. no. 9 we observe that half of all European SMEs who applied for a bank loan said that interest rates rose during April-September 2011, compared to 2009 when only $37 \%$ of managers reported an increase in interest rates. Other conditions of bank lending that were reported 
by SMEs that have deteriorated in 2011 compared to 2009 are finance costs other than interest rates (charges, fees, commissions) and collateral requirements. In the case of financing costs $48 \%$ of SMEs reported their deterioration in 2011, while in the case of collateral requirements $33 \%$ of SMEs reported their increase. Therefore a significant part of European SMEs reported deteriorating conditions and terms of bank lending.

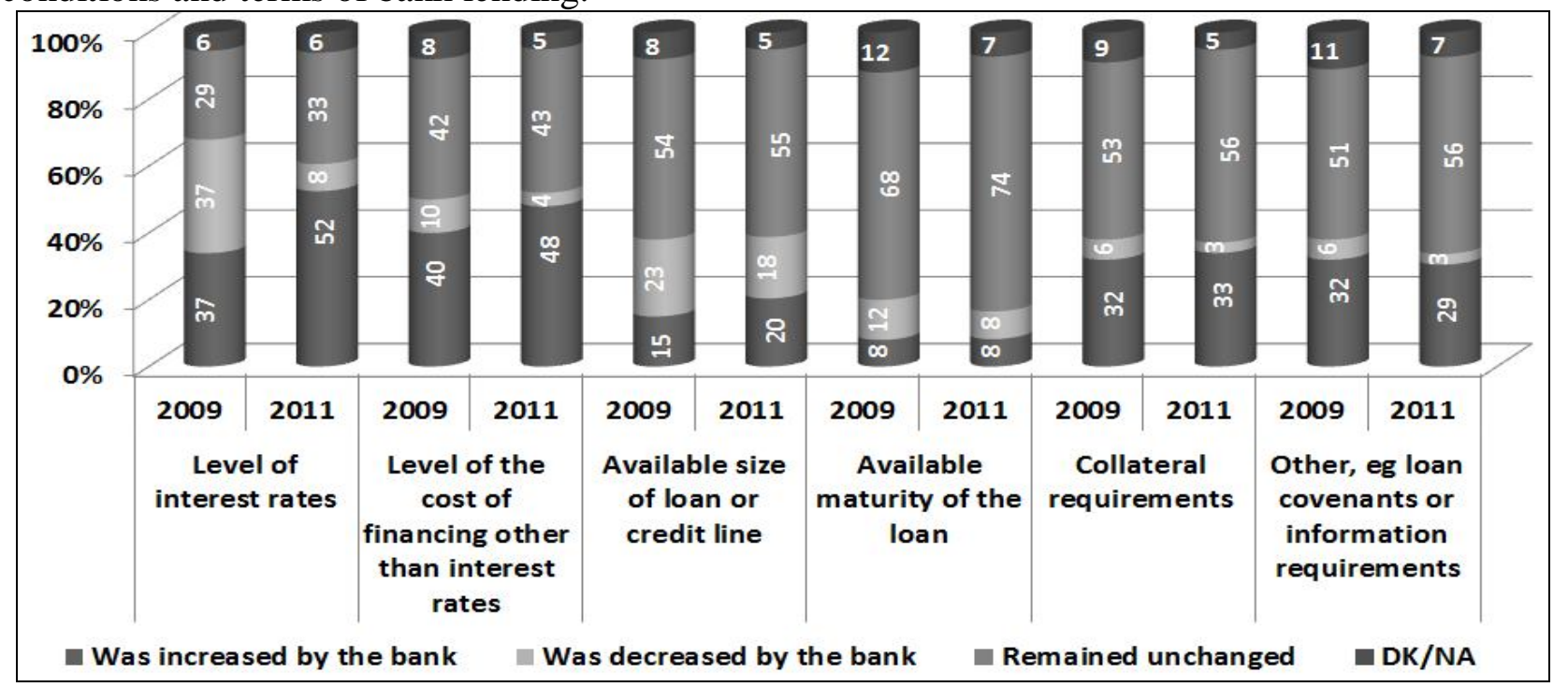

Fig. no. 9. - The modification of term and conditions of bank lending to SMEs in EU27

Source: (European Commission, 2011a)

Regarding the obstacles in obtaining external financing, $22 \%$ of SMEs stated that the main factor that would prevent them to obtain financing would be insufficiently collateral (or guarantee) and a similar proportion (20\%) said that interest rates and the price that could be seen as being too high) would limit their ability to attract financing. The proportion of SMEs which consider the interest rate as an obstacle has decreased slightly from $24 \%$ in 2009 to $20 \%$ in 2011 . Also a lower proportion of managers with ambitious growth $(3 \%)$ saw reduced control over their firm as an obstacle to obtain necessary financing, thus registering a dramatic reduction compared to 2009 $(33 \%)$. Only a small proportion of $6 \%$ of managers said that external financing is simply not available to them (see fig. no. 10).

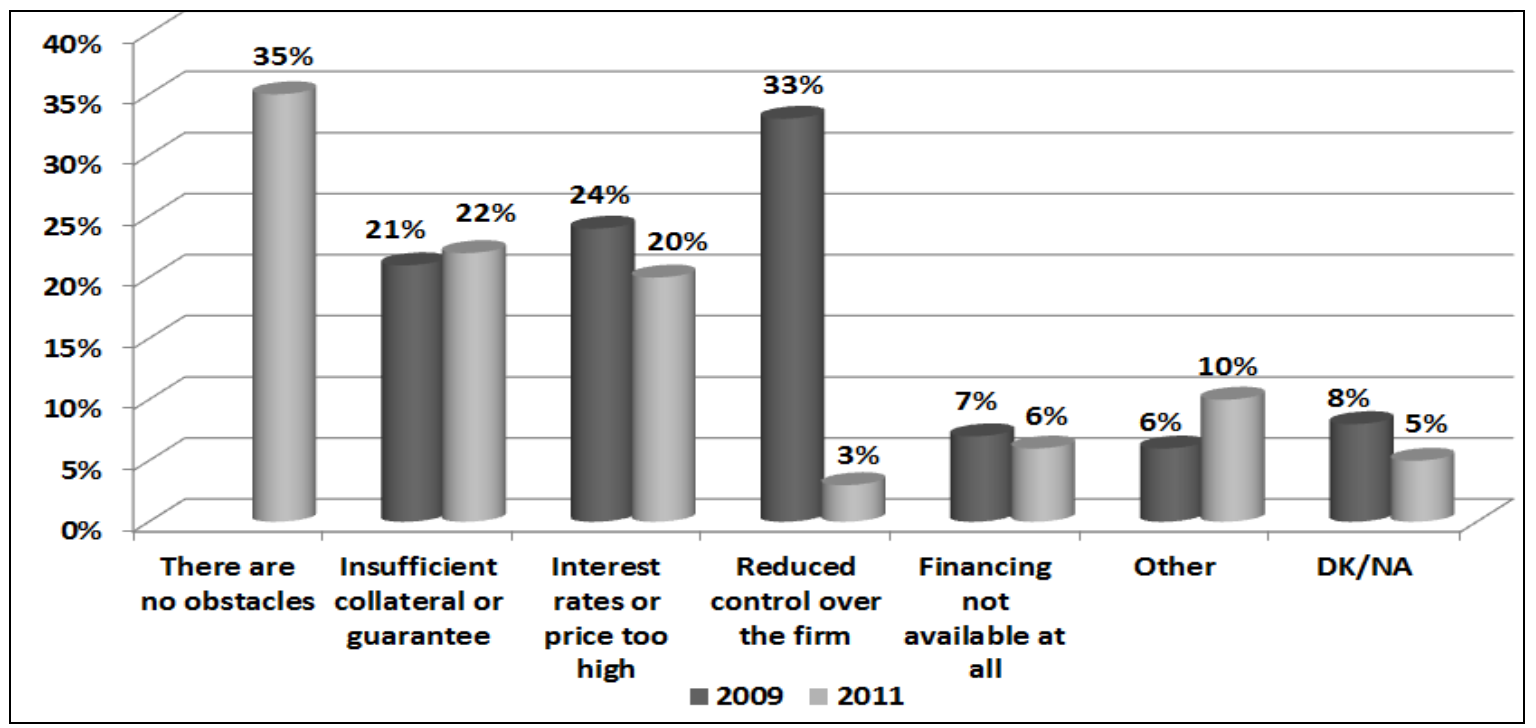

Fig. no. 10. - The most important limiting factors to get external financing Source: (European Commission, 2011a) 
In the context of the current crisis, the difficulties faced by SMEs on access to bank loans delay the exit of those firms from crisis, which is why the European Commission has intensified its concern for development of new courses of action to promote a better access to finance for SMEs. Thus, on December 7, 2011, in an Action Plan, the European Commission introduced new measures to support access to finance for SMEs (European Commission, 2011b). Referring to bank loans for SMEs, European Commission proposals target the strengthen of loans guarantee under the Programme for the Competitiveness of Enterprises and SMEs (COSME), maintaining lending to SMEs by the European Investment Bank and also following the improvement of the monitoring of SME lending to assess the impact of the measures to support SMEs finance and the new capital requirements applicable to banks.

In addition to the measures taken by the European Commission, an important role in improving access to finance for SMEs is granted to the interventions of national authorities, resulting in the government loan guarantee, strengthening capital base of support institutions, direct credit, export facilitation and credit mediation (see table no. 1).

Table no. 1

Government programs adopted in some EU countries to improve access to finance for SMEs in the period 2008-2011

\begin{tabular}{|c|c|c|c|c|c|c|c|c|}
\hline & $\begin{array}{r}\text { Govern } \\
\text { Gua } \\
\text { Prog }\end{array}$ & $\begin{array}{l}\text { ent Loan } \\
\text { antee } \\
\text { ammes }\end{array}$ & Strengthening & Direct & Ex| & ort facilit & ition & $\begin{array}{c}\text { Credit } \\
\text { Mediation } \\
\text { and }\end{array}$ \\
\hline & $\begin{array}{c}\text { Working } \\
\text { Capital } \\
\text { (Short- } \\
\text { term) }\end{array}$ & $\begin{array}{c}\text { Investment } \\
\text { Capital } \\
\text { (Long- } \\
\text { term) }\end{array}$ & $\begin{array}{l}\text { of support } \\
\text { institutions }\end{array}$ & & $\begin{array}{l}\text { Increased } \\
\text { capital of } \\
\text { export } \\
\text { support } \\
\text { institutions }\end{array}$ & $\begin{array}{l}\text { Export } \\
\text { Credits }\end{array}$ & $\begin{array}{c}\text { Export } \\
\text { Guarantees } \\
\text { or } \\
\text { Insurance }\end{array}$ & \\
\hline$\overline{\mathrm{AT}}$ & $\bar{X}$ & $\bar{X}$ & & $\bar{X}$ & & & & \\
\hline $\mathrm{BE}$ & $\mathrm{X}$ & $\mathrm{X}$ & $\mathrm{X}$ & $\mathrm{X}$ & $\mathrm{X}$ & & $\mathrm{X}$ & Mediation \\
\hline $\mathrm{CZ}$ & & & & & $\bar{X}$ & $\mathrm{X}$ & $\bar{X}$ & \\
\hline DK & $\mathrm{X}$ & $\mathrm{X}$ & & $\mathrm{X}$ & $\mathrm{X}$ & $\mathrm{X}$ & & Mediation \\
\hline FI & $\mathrm{X}$ & $\mathrm{X}$ & $\mathrm{X}$ & $\mathrm{X}$ & $\mathrm{X}$ & $\mathrm{X}$ & $\mathrm{X}$ & \\
\hline FR & $\mathrm{X}$ & $\mathrm{X}$ & $\mathrm{X}$ & $\mathrm{X}$ & & $\mathrm{X}$ & $\mathrm{X}$ & Mediation \\
\hline $\mathrm{DE}$ & $\mathrm{X}$ & $\mathrm{X}$ & & $\mathrm{X}$ & $\mathrm{X}$ & $\mathrm{X}$ & $\mathrm{X}$ & Mediation \\
\hline GR & $\mathrm{X}$ & & & & & & & \\
\hline $\mathrm{HU}$ & $\mathrm{X}$ & $\mathrm{X}$ & $\mathrm{X}$ & $\mathrm{X}$ & & & & \\
\hline $\mathrm{IE}$ & & & & & & & & Mediation \\
\hline IT & $\mathrm{X}$ & $\mathrm{X}$ & $\mathrm{X}$ & & & $\mathrm{X}$ & $\mathrm{X}$ & $\begin{array}{l}\text { Monitoring } \\
\text { and } \\
\text { collective } \\
\text { agreement }\end{array}$ \\
\hline NL & $\mathrm{X}$ & $\mathrm{X}$ & & $\mathrm{X}$ & & & $\mathrm{X}$ & Monitor \\
\hline PL & $\mathrm{X}$ & $\mathrm{X}$ & & & & & $\mathrm{X}$ & \\
\hline PT & $\mathrm{X}$ & $\mathrm{X}$ & & & & & & \\
\hline ES & $\mathrm{X}$ & $\mathrm{X}$ & & $\mathrm{X}$ & $\mathrm{X}$ & $\mathrm{X}$ & & Mediation \\
\hline SK & $\mathrm{X}$ & $\mathrm{X}$ & $\mathrm{X}$ & & $\mathrm{X}$ & $\mathrm{X}$ & $\mathrm{X}$ & \\
\hline UK & $X$ & $X$ & & $X$ & & & & \\
\hline $\mathrm{EE}$ & $\mathrm{X}$ & $\mathrm{X}$ & & $\mathrm{X}$ & & & $\mathrm{X}$ & \\
\hline
\end{tabular}

Source: (OECD, 2010: 53) 


\section{Current challenges faced by SMEs: Basel III Accord}

To function effectively the real economy needs well functioning financial markets. The current financial crisis has led to a redesign of the rules which are governing the financial market participants and the procedures for banking supervision. But, given the importance of the financial sector to national economies, it is necessary to conduct a thorough analysis of the effects of any new regulations to apply the correct procedures and to limit side effects to minimum.

The Bank for International Settlements (BIS) has developed new banking regulations, known as Basel III in order to strength the financial system. The need of a new framework to improve financial system strength is supported by all. Therefore Basel III, and its European version, the Capital Requirements Directive (CRD IV), which requires banks, among other things, to hold more capital, can have a negative impact on the access to finance for SMEs. Especially, in the European Union the negative impact can be more significant if we consider the dependence of SMEs on debt financing, and is more important than ever to develop alternative sources of financing for these firms, such as venture capital, micro-credit, leasing, and vehicles such as the new European Programme for the Competitiveness of Enterprises and SMEs (COSME).

Basel III is a new global regulatory standard, on bank capital adequacy and liquidity, agreed by the Basel Committee on Banking Supervision as a response to the deficiencies in financial regulation highlighted by the global financial crisis. Basel III further strengthens the bank capital requirements that were introduced in the Basel II framework and introduces new regulatory requirements on bank capital, liquidity and bank leverage. It will be introduced gradually over the period 2013-2019. Basel III puts a significant pressure on small banks especially in terms of calculating the risk and they will not be able to lend as easily as before, so SMEs will be most affected because will have to resort to large banks to obtain the financial resources they need. If small banks will not lend to SMEs, they will be forced to turn to the big banks to purchase capital, but because this large banks do not want to take big risks will have to select customers and the loans will certainly become more expensive.

Thus, it is essential to find the right balance between the need for financial stability and ensuring adequate access to finance for SMEs. With this purpose, it is likely to be needed that the risk weights for loans to SMEs to be revised when will be implemented Basel III rules on capital requirements in the EU, and alternative sources of financing, such as equity - oriented instruments and leases, must be further developed and encouraged.

Basel III implementation has important consequences for both banks and SMEs borrowers. For banks, the new banking regulation means operating in a more stable financial environment. Once the banks have learned how to measure, cover, and manage the risks to which their operations are exposed, they should face fewer cases of default, but if such circumstances arise they should be better prepared to deal with them. For SMEs, The Capital Agreement means the payment of premiums according to risk of their business initiatives. In the past, the restrictions involved in SMEs access to loans resulted mainly from the difficulty to calibrate risk which they represented for the banks. At the same time, SMEs must be trained in risk management, knowing that the lender will evaluate them in this respect (Cardone-Riportella, Trujillo-Ponce, Briozzo, 2011).

Thus, the impact of Basel III on the microeconomic level is estimated that there is a risk that the new prudential rules lead to a significant deterioration in the terms and conditions of SME lending, especially by increasing interest to allow banks to cover additional costs of implementing Basel III (BeCeFi, 2012). Tightening credit conditions, especially for small and medium-sized companies and start-up businesses, which are considered risky by banks, is due to the fact that, after the new capital requirements, banks will have to increase their funds when the risk increases. The banks, especially those overleveraged and small banks will be forced to restrict, temporarily, the access to loans for firms, especially by increasing interest rates, which will reduce the amount of loans distributed to SMEs (Dun and Bradstreet, 2010). Also, the new capital requirements could determine banks to take fewer risks related to financing of the firms in the seed stage or survival 
stage; so that Basel III could lead to a significant reduction in the number of new established companies or could even prevent firms from passing from the survival stage to the profitability stage (BeCeFi, 2012).

In terms of the banking practice, the impact of new regulations on capital requirements on lending rules can be highlighted on the survey conducted by the European Central Bank on a sample of euro area banks. The survey results show for the first half of 2012 that $25 \%$ of banks surveyed reported a tightening of credit conditions for loans granted to large companies as a result of adjustments to the new rules on capital requirements, while only $8 \%$ of banks reported a tightening of credit standards for loans to SMEs (see fig. no. 11). For the second half of 2012, euro area banks expect a sharper tightening of lending standards as a result of regulatory pressure for loans to enterprises (ECB, 2012, p. 17).

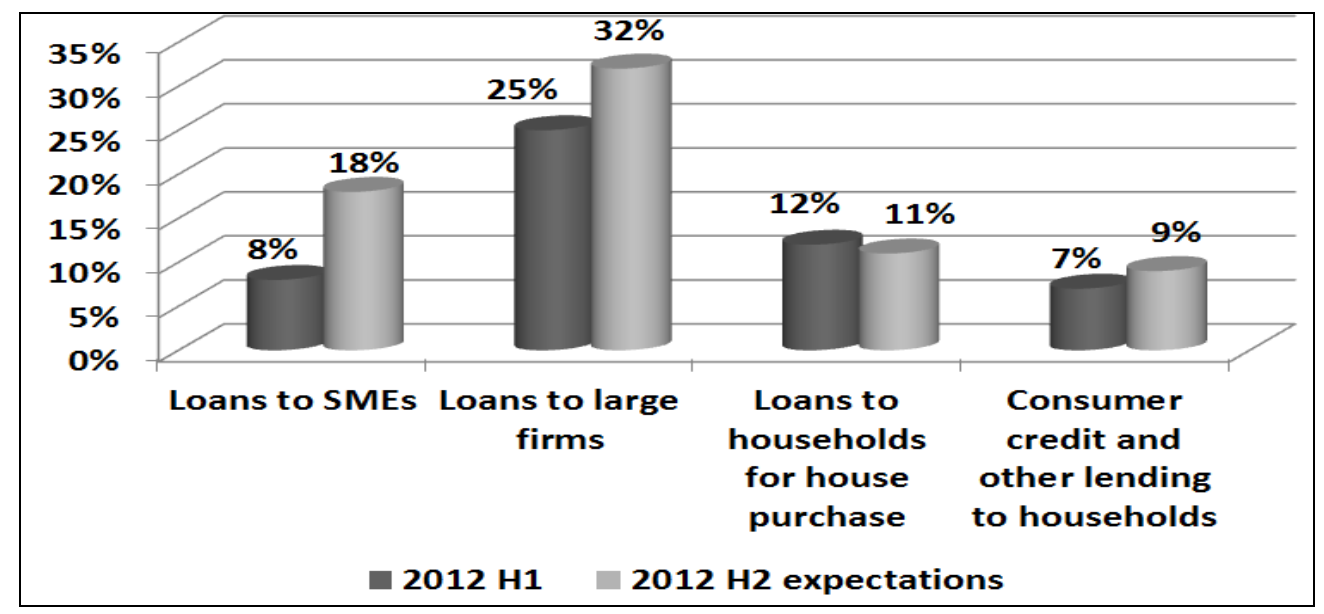

Fig. no. 11. - The impact of Basel III and of some other regulatory requirements on the
tightening of credit standards (net percentages of banks)
Source: processing based on ECB, 2012

Given the major role of the SME sector in the European economy and the crucial importance of easy access to finance in this sector for overcoming the crisis and economic recovery, the European Commission aims to improve, within the CRD IV, the favorable treatment of SME exposures, for example, by reducing the risk weighting from $75 \%$ to $50 \%$ or increasing the exposure threshold for SMEs from 1 million euro to 2 million euro or to 5 million euro (European Commission, 2012).

By the implementation of Basel III Accord it is aimed the increase of the resilience of the global financial system in order to mitigate and even to prevent the future financial crises, but it is possible that its effects on SME financing by loans to be negative. So far, there aren't studies on the impact of the new rules on lending to SMEs so that we can not make judgments about the magnitude of the effect.

Since bank loans are a vital resource for SMEs financing because of the reduced possibilities of these firms to find alternative sources of financing, strengthening the long-term stability of the banking sector by the new rules under Basel III could represent a significant progress for these firms. On the other hand, Basel III may be costly in the short term by the negative impact of new banking regulations on bank financing of the real economy, especially of small and medium-sized companies. Thus, reduced access to loans for these companies may hamper the recovery of the European economies. Therefore, although Basel III represents a significant progress for strengthening financial stability it must be found a balance between the need for stricter prudential rules to enhance the strength of the financial system and the need of normal credit flows to SMEs (UEAPME, 2012). 


\section{Conclusions}

The banks' loaning process represents for the small and medium size enterprises a major external financing modality in the context of lesser financing alternatives because these firms do not have direct access to the financial markets, and venture capital European markets are underdeveloped.

In the context of the current crisis we can acknowledge that in most of the major EU countries there has been a diminishing of the banks' loans availability for the SMEs, these firms facing real difficulties regarding their financing that can endanger their survival and their overcoming of the crisis. The undertaken analysis highlights a deterioration of the terms and conditions for granting banking loans for a significant part of the European SMEs, reflected especially through the raise of the financing costs and the tightening of the collateral requirements for the firms. Moreover, the application of the new banking rules set by the Basel III Agreement could lead to an even worst and deep deterioration of the availability of bank loans for SMEs, that could delay the recovery of the economy.

Although the implementation of the Basel III aims to increase the resistance and the stability of the financial-banking sector in order to mitigate and even prevent future financial crises, it is possible that its effects on SMEs financing by loans to be negative. In this context, it is needed the adoption of measures by the European and national authorities for the development of alternative financing sources for the SMEs, like venture capital, micro-credit, leasing, financial vehicles such as the new European Programme for the Competitiveness of Enterprises and SMEs.

The added value of our paper results from how it highlights some key features of European SMEs access to bank loans in 2009 and 2011, but mostly from the discusses about the possible impact of new banking regulations on loans for SMEs.

Our research has some limitations related, in particular, on the reduced availability of statistical data on bank lending to SMEs. In our future research, we propose to analyze the potential risks of the new banking regulations on SMEs access to bank financing and to evaluate the impact of new banking prudential requirements on bank loans granted to SMEs.

\section{References}

1. Angelkort A., Stuwe A., 2011. Basel III and SMEs financing, Friedrich-Ebert-Stiftung Zentrale Aufgaben, Germany.

2. Altman E., Sabato G., 2005. Effects of the New Basel Capital Accord on Bank Capital Requirements for SMEs, Journal of Financial Service Research, Volume 28, pp. 15 - 42.

3. Ardic O.P., Mylenko N., Saltane V., 2011. Small and Medium Enterprises: A Cross-Country Analysis with a New Data Set, World Bank Policy Research Working Paper 5538

4. Bank for International Settlements, 2010. Basel III: A global regulatory framework for more resilient banks and banking systems, Basel Committee on Banking Supervision, available online at http://www.bis.org/publ/bcbs189_dec2010.pdf

5. Barth J., Lin D., Yost K., 2011. Small and Medium Enterprise Financing in Transition Economies, Atlantic Economic Journal, No. 39, pp. 19-38

6. Beck T., Demirgüç-Kunt A., Laeven L., Maksimovic V., 2006. The Determinants of Financing Obstacles, Journal of International Money and Finance, No. 25, pp. 932-952

7. Beck T., Demirgüç-Kunt A., Martínez Pería M. S., 2011. Bank Financing for SMEs: Evidence Across Countries and Bank Ownership Types, Journal of Financial Services Research, No. 39, pp. 35-54

8. Beck T., Demirgüç-Kunt A., Martínez Pería M.S., 2009. Bank Financing for SMEs: Evidence Across Countries and Bank-ownership Types, European Banking Center Discussion, Paper No. 2009-20 
9. Belgian Knowledge Centre for SME Financing (BeCeFi), 2012. The impact of Basel III on SME financing, Working Paper Series, April, available online at http://www.cefip.be/FILES/Documenten/FR/ImpactBaleIII_FR.pdf

10. Cardone-Riportella C., Trujillo-Ponce A., Briozzo A., 2011. What do Basel Capital Accords mean for SMEs?, Working Paper 10, Business Economic Series, Getafe, Spain

11. De Kok J., Vroonhof P., Verhoeven W., Timmermans N., Kwaak T., Snijders J., Westhof F., 2011. Do SMEs create more and better jobs?, EIM Business \& Policy Research, Zoetermeer, November

12. De la Torre A., Martinez Peria M.S., Schmukler S., 2008. Drivers and Obstacles to Banking SMEs: The Role of Competition and the Institutional Framework, The World Bank, Policy Research Working Paper 4788

13. Dun\&Bradstreet, 2010. The Business Impact of Basel III. Special Report, October, available online at http://www.dnbgov.com/pdf/DNBBaselIII.PDF

14. ECB, 2012. The Euro Area Bank Lending Survey, July, available online at http://www.ecb.int/stats/money/surveys/lend/html/index.en.html

15. ECB, 2011. Financing Obstacles Among Euro Area Firms: Who Suffers the Most?, Working Papers Series, No. 1293

16. European Commission, 2012. Second Report on Effects of Directives 2006/48/EC and 2006/49/EC on the Economic Cycle, COM(2012) 400 final, Brussels, 17.7.2012.

17. European Commission, Enterprise and Industry (SAFE), 2011a. SMEs' Access to Finance, Survey 2011. Analytical Report, December.

18. European Commission, 2011b. Commission Staff Working Paper, Impact Assessment. Accompanying the document Regulation of the European Parliament and the Council on prudential requirements for the credit institutions and investment firms, COM(2011) 452 final, Brussels, 20.7.2011.

19. Hernandez-Canovas G., Martinez-Solano P., 2010. Relationship lending and SME financing in the continental European bank-based system, Small Business Economics, No. 34, pp. 465-482.

20. Mercieca S., Schaeck K., Wolfe S., 2009. Bank Market Structure, Competition, and SME Financing Relationships in European Regions, Journal of Financial Services Research, Volume 36, Issue 2-3, pp. 137-155.

21. OECD, 2010. Assessment of Government Support Programmes for SMEs' and Entrepreneurs' Access to Finance in the Global Crisis, OECD Working Party on SMEs and Entrepreneurship' Bologna+10' High-Level Meeting on Lessons from the Global Crisis and the Way Forward to Job Creation and Growth, available online at http://www.oecd.org/cfe/smesandentrepreneurship/Assessment_Government_Support_Progr ammes.pdf

22. Roman A., 2012. Sources of financing European SMEs and new supporting EU policies: evidence from the new EU member states, The Annals of the University „Tibiscus”, Timişoara, Romania, Economic Science Series, Volume XVIII, pp. 245-252.

23. Schiffer M., Weder B., 2001. Firm Size and the Business Environment: Worldwide Survey Results, Discussion Paper No. 43, International Finance Corporation, Washington D.C.

24. UEAPME, 2012. Basel III: Parliament's committee vote a key step in the right direction, say SMEs, Press releases, Brussels, 15 May, available online at http://www.ueapme.com/IMG/pdf/120515_pr_Basel_III_vote_ECON.pdf

25. World Bank, 2011. Doing Business 2012: Doing Business in a More Transparent World, available online at http://www.doingbusiness.org/reports/global-reports/doing-business2012 